\title{
Variant Angina
}

National Cancer Institute

\section{Source}

National Cancer Institute. Variant Angina. NCI Thesaurus. Code C66915.

A variant form of angina pectoris caused by coronary artery vasospasm, usually occurring spontaneously and frequently associated with ST segment elevation. 